\title{
DijANa ĆURKović
}

\section{ACCENT PARADIGMS OF $\boldsymbol{A}$-TYPE MASCULINE NOUNS IN THE NEO-ŠTOKAVIAN IKAVIAN LOCAL DIALECT OF BITELIĆ}

\section{Naglasne paradigme ajevskih samostalnikov moškega spola \\ v novoštokavskem ikavskem govoru naselja Bitelić na Hrvaškem} Prispevek opisuje del naglasnega sistema govora naselja Bitelić, ki se nahaja blizu Sinja (ob meji med Hrvaško ter Bosno in Hercegovino na ozemlju novoštokavskega ikavskega narečja). Raziskava se posveča le samostalnikom moškega spola sinhrone ajevske sklanjatve (diahrono so to izvorno večinoma samostalniki moškega spola ojevske sklanjatve).

Ključne besede: novoštokavščina, ikavščina, govori, naglasne paradigme, ajevski samostalniki

This article describes a part of the accentual system in Bitelić, which is located in the vicinity to Sinj, near the border between Croatia and Bosnia and Herzegovina, in the territory of the Neo-Štokavian ikavian dialect. Only masculine nouns are examined, and only those inflecting following the synchronic $a$-type declension (diachronically, these are mostly $o$-stem masculine nouns).

Keywords: Neo-Štokavian, Ikavian, subdialects, accent paradigms, $a$-type nouns

\section{THE NEO-ŠTOKAVIAN IKAVIAN DIALECT AND THE LOCAL DIALECT OF BITELIĆ}

The local dialect of Bitelić1 belongs to the NŠI, 2 which extends from the Adriatic coast south of the city of Zadar and north of the Pelješac Peninsula, through interior Dalmatia, Herzegovina, western Bosnia, and individual villages in Lika, Gorski Kotar, northern Bosnia around the city of Derventa, and Bačka and Banat in Serbia

This article was presented at the third Slavic studies conference, as part of which the Department of Slavic Languages at the University of Ljubljana's Faculty of Arts hosted the Tenth International Workshop on Balto-Slavic Accentology (10. mednarodna konferenca o baltoslovanskem naglasoslovju / Х Международный семинар по балто-славянской акиентологии, IWoBA $\mathrm{X}$ ) from October 16th to 18th, 2014. - The article is adapted from the author's dissertation (Ćurković 2014), and the material is both somewhat shortened and somewhat expanded. Compared to the dissertation, this article introduces the subdialects and shows the accent paradigm subtypes separately from the main paradigm types.

1 Basic historical, geographic, and demographic information about the village, as well as a description of the research methodology, can be found in Ćurković (2014: 3-29).

2 Abbreviations: a.p. = accent paradigm; cases: $\mathrm{N}=$ nominative, $\mathrm{G}=$ genitive, $\mathrm{D}=$ dative, $\mathrm{A}=$ accusative, $\mathrm{V}=$ vocative, $\mathrm{L}=$ locative, $\mathrm{I}=$ instrumental; genders: $\mathrm{f}=$ feminine, $\mathrm{m}=$ masculine, $\mathrm{n}=$ neuter; $\mathrm{sg}=$ singular, $\mathrm{pl}=$ plural, NŠI $=$ Neo-Štokavian ikavian dialect. 
(cf. Lisac 2003: 50-51). Considering its territorial diversity, the NŠI can be divided into subdialects that differ in particular features. These subdialects are (1) the coastal subdialect, which includes areas on Pelješac, certain areas of the former Poljica Republic, and the Makarska coast; (2) the continental Dalmatian subdialect, differing by the vicinity (or hinterland) of cities: Imotski, Vrgorac, Sinj, Šibenik, and Zadar; (3) the Bosnia-Herzegovinian subdialect, spoken in the Rama area, near the city of Livno, in southern Bosnia, around the city of Bihać, and around Derventa; and (4) the emigrant subdialect, spoken in Lika and Gorski Kotar, in Bačka and Banat, in Molise (Italy), in Perth (Australia, whose immigrants arrived there from Molise), and elsewhere. 3 The local dialect of Bitelić is therefore classified in the continental Dalmatian subdialect, as part of the local dialect group in the vicinity of Sinj.

The local dialects in the vicinity of Sinj differ from other NŠI systems in several features. In the consonant system, there is a feature found only in the vicinity of Sinj: the devoicing of voiced consonants and $v$ in final position of phonetic words 4 before a word beginning with a vowel, sonant, or another voiced or unvoiced consonant. In the vowel system, there are many alterations and even more reductions of short unaccented vowels. 5

The accentual system consists of five units: four accents (short falling $\ddot{a}$, long falling $\hat{a}$, short rising $\grave{a}$, and long rising $a$ ) and an unaccented length $(\bar{a})$, which is always post-tonic. The relevant features are stress, length, and tone of the accented syllable. Unaccented syllables differ by length in three degrees: long, short, and hyper-short (or reduced) syllables. The last have resulted from partial reduction, and thus their articulation is neutralized to $a$ in particular cases, especially in free speech. 6

Rising accents are results of NŠI retraction, and as such cannot be found on the last syllable of a word (except after reduction of a final short unaccented syllable, which is a more recent innovation in the system; see below). The NŠI retraction applied to all falling accents in non-initial position; accents retracted from the final syllable to the penultimate, or from the medial syllable to the one preceding it. If the syllable preceding the old accent (i.e., the syllable to which the stress retracted) had a pre-tonic length, the resulting accent is a long rising accent, and, if that syllable was short, the result is a short rising accent ( $\mathrm{n} \mathrm{N} \mathrm{sg}$ sèlo < *selö 'village', f N sg gláva < *glāvä 'head'). Therefore, in the majority

3 Particular areas of the subdialects have been described in dialectology terms. For example, parts of the coastal subdialect are noted in Kurtović Budja (2009), Tomelić Ćurlin (2012), and Tomelić Ćurlin - Ćurković (2013); and continental Dalmatian areas are covered in Bošnjak Botica and Menac-Mihalić (2006), Čilaš Šimpraga (2010), Kapović (2006), Lisac (2003), Listeš (1998), Menac-Mihalić (2005), Šimundić (1971), and Tomelić Ćurlin and Anić (2012). It should be noted that not all of these works are equally detailed. Šimundić (1971), Ćurković (2014), Kurtović Budja (2009), and Menac-Mihalić (2005) are larger works, whereas the rest are articles and book chapters. Further reading can be found in Lisac $(2003,2005,2006)$.

4 A phonetic word consists of an accented word and its proclitics and enclitics.

5 Several more distinctions can be found in Ćurković (2014).

6 Reduction is described in Ćurković (2014: 37-47). 
of cases, the falling accents are retracted to the preceding syllable. Exceptions are noted in several positions typical for NŠI (f N sg poḷoprîvreda 'agriculture', $\mathrm{m} \mathrm{G} \mathrm{pl} \mathrm{muškârācă} \mathrm{'men').} \mathrm{Since} \mathrm{the} \mathrm{rising} \mathrm{accents} \mathrm{are} \mathrm{results} \mathrm{of} \mathrm{retractions,} \mathrm{they}$ can only be found in non-final positions. However, due to the innovative reduction of short unaccented syllables, they can also appear in monosyllabic words and in the final syllable (imperative $2 \mathrm{sg}:$ piš $<$ pís ${ }^{i}<$ piši $i<*$ pīsìi ' write', donès $<$ donès ${ }^{i}<$ donèsi $<*$ donesï 'bring'). Reduction is a phonetic variation and not a phonological change because it may or may not occur in free speech. ${ }^{7}$

Post-tonic length can be shortened in free speech if there are more than two post-tonic lengths in a word. The stress is often transferred to the proclitic, in the form of transmission (prenošenje; the stress moves to the preceding syllable, sg N küća, G okò kućé, A ù kuću 'house') or skipping (preskakanje; the stress moves to the initial syllable of the phonetic word, sg N gláva, A nä glāvu 'head'). In the local dialect of Bitelić, transmission is a feature of a.p. A (it seldom occurs in a.p. B as well), and stress skipping is a feature of a.p. $\mathrm{C}(\mathrm{sg} \mathrm{N} b o g, \mathrm{~A} \ddot{u} b o g a)$. The features of the accent paradigms are further described below, but first the inflection will be observed.

\section{BASIC INFORMATION ON THE A-TYPE DECLENSION}

The inflection of nouns in Croatian is divided into four major synchronic declension patterns, named after the suffix for the G sg: $a$-type masculine nouns, $a$-type neuter nouns, and $\bar{e}$-type and $i$-type feminine nouns. The difference between $a$-type masculine and neuter nouns is in equalization of case suffixes. In the masculine declension, the A sg is the same as the G sg if the noun denotes a living being, and the same as the $\mathrm{N}$ sg if the noun denotes an inanimate object (A sg lóvca 'hunter' : bôr 'pine'), 8 whereas neuter nouns have NAV merger in the sg and pl declension regardless of the meaning of the noun. Other mergers, such as DL sg, NV pl, and DLI pl, are present in the inflection of nouns of all genders, which is a typical feature of NŠI. In the masculine declension, the suffix for the A pl is different from that for the $\mathrm{N} \mathrm{pl}$, whereas the neuter and feminine declensions have NAV pl merger.

The inflectional suffixes for the $a$-type masculine declension are: $\operatorname{sg} \mathrm{N} \emptyset$, $\mathrm{G}-a, \mathrm{D}-u, \mathrm{~A}-a$ animate $\} / \emptyset$ inanimate $, \mathrm{V}-u /-e, \mathrm{~L}-u, \mathrm{I}-$ on $(-e n) ; \mathrm{pl} \mathrm{N}-i, \mathrm{G}-\bar{a}$, $\mathrm{D}-\bar{i} n /-i m a(n), \mathrm{A}-e, \mathrm{~V}-i, \mathrm{~L}-\bar{i} n /-i m a(n), \mathrm{I}-\bar{\imath} n /-i m a(n)$.

$7 \quad$ All of the realizations (such as piši $i$, piši ${ }^{\prime}$, piš) are confirmed in the data.

8 If a noun stands for a group of people, it acts as though it is inanimate: NA sg skûp 'assembly', sâbor 'parliament', sávjet 'council'. Nouns that denote plants are grammatically inanimate despite being living beings: NA sg òras/òraj 'walnut' ( $-s$ is generalized in all cases based on the N $\mathrm{pl}$ ending of the root, which goes through sibilantization orahi $>$ orasi, and $-j$ is a regular replacement of $h$, which is not a stable phoneme in NŠI, cf. Lisac 2003: 18, 2003a: 176; Čilaš Šimpraga 2010: 194; Kurtović Budja 2009: 55-57; Kapović 2006: 114; Šimundić 1971: 51-52; Tomelić Ćurlin - Anić 2012: 355; Ćurković 68-69), këstēn 'chestnut' (with lengthening of $e$ before - $n \#$, cf. Ćurković 2014: 110). Certain nouns with inanimate meanings act as though they were animate; AG sg za Hajdúka/Ajdúka 'hero' (which is a name of a soccer club from the city of Split). 
The inflectional root is determined from the $\mathrm{G} g$ because not all of the $a$-type masculine nouns have the same $\mathrm{N} \mathrm{sg}$ inflectional root ending, this being either a consonant or the vowels - o or - $a$ (čòvik'man', stô 'table', pòsā 'job'). Furthermore, some of the nouns have a fleeting $a$, which is a result of vocalization of $*_{b} / b$ in the last syllable in the $\mathrm{N} \mathrm{sg}$, and in the middle one in the $\mathrm{G} \mathrm{pl}$ (which is most commonly long), whereas the vocalization is absent in other cases that have a vowel in the inflectional suffix: $\mathrm{N}$ sg nòvac, G sg nóvca, G pl növācā 'money'; $\mathrm{N}$ sg žábac, G sg žápca, $\mathrm{G}$ pl žâbācā 'male frog'; $\mathrm{N}$ sg òtac, $\mathrm{G}$ sg òca, $\mathrm{G}$ pl otácā 'father' .9

The suffix for the $\mathrm{V} \mathrm{sg}$ is $-e$ in most of the nouns, and it palatalizes the inflectional root: V sg böže 'god', vîče 'wolf'. If the root ends with a palatal consonant, the suffix is -u: V sg köńu 'horse', mlädīću 'youngster', prïjatel̦u 'friend'.

The suffix for the I sg has the distinction -on \{non-palatal consonant\}: -en \{palatal consonant\} only in the free speech of the younger generations, whereas the non-palatal suffix prevails in the speech of older generations, which is a feature of the wider NŠI area.10 It should be noted that the I sg and pl forms often appear together with the preposition $s / s a$, regardless of the meaning (\{company $\}$ : \{instrument\}; e.g., prîčān s bräton 'I am talking to my brother', rǐžěs s nóžon 'you are cutting with a knife').

Similarly, the plural infix -ov- (-ev-) can either be present in the formation of the plural, as in $\mathrm{N}$ pl brïgovi 'hills', dïlovi 'parts', müžovi 'husbands', or absent, as in $\mathrm{N}$ pl cr̀vi 'worms', klúíci 'keys', mrâvi 'ants'; or the plural can be realized with or without the infix, depending on the speech situation: N pl rözi/rögovi 'horns', gölūbi/gölubovi 'pigeons', nóži/nöžovi 'knives'.

It is seen from the above examples that roots ending with a velar consonant $(k, g, h)$ undergo sibilantization to $c, z, s$ before $-i$, which also occurs in the DLI pl, with the variation -īn/-ima(n): $\mathrm{N}$ sg vûk, $\mathrm{N}$ pl vîci, DLI pl vûcin/vûcima(n), 'wolf', $\mathrm{N}$ sg bùbrig, $\mathrm{N}$ pl bùbrizi, DLI pl bùbrizīn/bùbrizima(n) 'kidney', etc.

The suffix for the $\mathrm{G}$ pl is $-\bar{a}$ in most cases, except in nouns denoting measurement

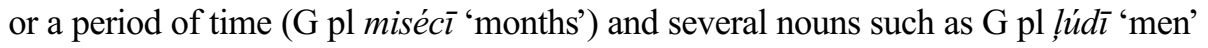
(suppletive form of čovik 'man'), G pl mrávī 'ants', and nouns that have the suffix -ijü: G pl gòstijū 'guests', pristijū 'fingers', nòktijū 'nails', cr̀vijū 'worms', zùbijū 'teeth'.

\section{ACCENT PARADIGMS OF A-TYPE NOUNS IN BITELIĆ}

The declension patterns of $a$-type nouns are divided into three major synchronic groups, a.p. A, B, and C, as well as the subtypes B-A (B-A/B) and C-A. Each is described on the basis of paradigm examples, and a list of words declining in accordance with that pattern is given.

9 Consonant assimilations and omissions in Bitelić are described in Ćurković (2014: 77-87).

10 Cf. Ćurković (2014: 139), Kurtović Budja (2009: 79), Lisac (2003: 56), Menac-Mihalić (2005: 49), Šimundić (1971: 37). 
Generally speaking, in a.p. A stress is on the same syllable of the root throughout the paradigm; in a.p. B suffixes attract the stress, which results in a short or long rising accent on the last syllable of the root of case forms consisting of more than one syllable; and in a.p. C the stress is mobile in the paradigm, which means that it is on the initial syllable of the phonetic word, unless the inflectional suffix of the case is dominant (cf. Kapović 2015: 74-76), and the stress is closer to the ending, which results in a short or long rising accent on the last syllable of the root, similarly to a.p. B, or the penultimate syllable of the word. The subtypes $\mathrm{B}-\mathrm{A}$ $(\mathrm{B}-\mathrm{A} / \mathrm{B})^{11}$ and $\mathrm{C}-\mathrm{A}$ include words declining following a.p. $\mathrm{B}$ and $\mathrm{C}$ in sg cases, and a.p. A in pl cases.

In all of the paradigm types, in the $\mathrm{V}$ sg the stress is drawn to the initial syllable as a falling accent (a.p. A N sg čòvik, V sg čôviče 'man'; a.p. B N sg vòjnīk, V sg vöjniče 'soldier', a.p. C N sg rôd, V sg röde 'kin, gender'), as well as in the $\mathrm{G} \mathrm{pl}$, in addition to the last two syllables being long in the $\mathrm{G} \mathrm{pl}$ (a.p. A mëdvidda 'bears', a.p. B lôvācā 'hunters', a.p. C bödōva 'points').

A difference in tone in the $\mathrm{D}$ and $\mathrm{L} \mathrm{sg}$ is noted in a.p. A and, more commonly, in a.p. C (a.p. A: D sg prägu, L sg na pràgu 'doorstep'; D sg rät, L sg u ràtu 'war'; a.p. C: D sg grâdu, L sg u grádu 'city'; D sg glâsu, L sg po glásu 'voice'), although there are exceptions (such as D sg jügu, L sg na jügu 'south').

\subsection{Accent paradigm A}

In a.p. A, the stress is in the same position on the root in all case forms. A number of nouns have a short (or rarely long) falling accent on the first syllable throughout the paradigm (däbar 'beaver', blud 'lust'), and other examples have a rising tone in non-final position (jèzik 'language, tongue', mèdvid 'bear'). If the stress is drawn from the falling accent on the first syllable of the root to a proclitic, the result is a transmission of accent; that is, a rising accent on the preceding syllable: $\mathrm{N}$ sg präg, A sg nà prag 'doorstep'. If the stress moves from a long falling accent, post-tonic length remains after the transmission: $\mathrm{N}$ sg krâj, A sg nà krāj 'ending, area'. It should also be noted that a number of nouns do not have the expected falling accent in the $\mathrm{G} \mathrm{pl}$ (čèkićc ' 'hammers', čèmērā 'sorrows', jèzìk $\bar{a}$ 'languages, tongues', pòtōk $\bar{a}$ 'brooks'), whereas other nouns can be realized with both falling and rising tone: $\mathrm{G}$ pl dùkātāaldükātā 'coins, ducats'.

Tables 1-4 show a.p. A examples of monosyllabic nouns with and without the plural infix -ov-, and polysyllabic words with rising accents, as well as those with lengthening before $-n \#$, which all belong to a.p. A synchronically.

11 " $\mathrm{B}-\mathrm{A} / \mathrm{B}$ " designates nouns that belong to a.p. $\mathrm{A}$ in the longer realization of the $\mathrm{pl}$ form, and a.p. $\mathrm{B}$ in the shorter: $\mathrm{N}$ sg br̈k, G sg brka, $\mathrm{N}$ pl brkkovi/brrci 'moustache'. 
Table 1: Declension of $\boldsymbol{j a ̈ d}$ ' 'misery'

\begin{tabular}{|c|c|c|}
\hline & sg & pl \\
\hline $\mathbf{N}$ & jäd & jädi \\
\hline $\mathbf{G}$ & jäda / òd jada & jâdā / òd jāada \\
\hline D & jädu & jädìn/jädima(n) \\
\hline $\mathbf{A}$ & jäd / nà jad & jäde / nà jade \\
\hline $\mathbf{V}$ & jäde & jädi \\
\hline $\mathbf{L}$ & ò jadu / jädu / u jàdu & ò jadīn / jädīn / jädima(n) \\
\hline I & jädon & jädīn/jädima(n) \\
\hline
\end{tabular}

Table 2: Declension of pòtok 'brook'

\begin{tabular}{|c|c|c|}
\hline & sg & pl \\
\hline $\mathbf{N}$ & pòtok & pòtoci \\
\hline $\mathbf{G}$ & potoka & pòtōka \\
\hline D & pòtoku & pòtocīn/pòtocima(n) \\
\hline $\mathbf{A}$ & pòtok & pòtoke \\
\hline $\mathbf{V}$ & pòtoče & pòtoci \\
\hline $\mathbf{L}$ & o pòtoku & pòtocīn/pòtocima(n) \\
\hline I & pòtokon & pòtocīn/pòtocima(n) \\
\hline
\end{tabular}

Table 3: Declension of $\boldsymbol{d} \ddot{\boldsymbol{d}} \boldsymbol{\alpha}$ 'grandfather'

\begin{tabular}{|c|c|c|}
\hline & sg & pl \\
\hline $\mathbf{N}$ & did & dìdovi \\
\hline$\underline{\mathbf{G}}$ & dìda / òd dida & didōvvā / òd didōvā \\
\hline D & dìdu & dïdovīn/dïdovima(n) \\
\hline $\mathbf{A}$ & dìda / nà dida & dïdove / zà didove \\
\hline$\underline{\mathbf{V}}$ & dide & didovi \\
\hline$\underline{\mathbf{L}}$ & òdidu / dìdu & ò didovīn / dìdovīn / dìdovima(n) \\
\hline I & dìdon & dïdovīn/dïdovima(n) \\
\hline
\end{tabular}

Table 4: Declension of jëlēn 'deer'

\begin{tabular}{|c|c|c|}
\hline & sg & pl \\
\hline $\mathbf{N}$ & jëlēn & jëlēni \\
\hline $\mathbf{G}$ & jëlēna / òd jelēna & jëlēnā / òd jelēnā \\
\hline$\underline{\mathbf{D}}$ & jëlēnu & jëlēnīn/jëlēnima(n) \\
\hline$\underline{\mathbf{A}}$ & jëlēna / nà jelēna & jëlēne / zà jelēne \\
\hline $\mathbf{V}$ & jëlēnu & jëlèni \\
\hline$\underline{\mathbf{L}}$ & ò jelēnu / jëlēnu & ò jelēnīn / jëlēnīn / jëlēnima(n) \\
\hline I & jëlēnon & jëlēnīn/jëlēnima(n) \\
\hline
\end{tabular}


Nouns that belong to a.p. A: bàjam 'almond', blûd 'lust' (G sg blûda), bôd 'point' (G sg böda), brät 'brother', 12 br̀log 'lair', čèkić 'hammer', čèmer 'sorrow', čòvik 'man', däbar 'beaver' (G sg däbra), dìd 'grandfather', dìm 'smoke', dlän 'palm, hand', dùkat 'coin, ducat', gräb 'hornbeam', jäd 'misery', jëlēn 'deer', jèzik 'language, tongue', jüg 'south', gövōr 'speech', güšter 'lizard', käšal 'cough' (G sg käšl la), klïn 'linchpin', krâj (G sg kräja) 'ending, area', krèvet 'bed', krüv 'bread', län 'flax', läv 'lion', lük 'garlic', mäk 'poppy', mèdvid 'bear', nëća k 'nephew', öbičàj 'custom',13 öblāk 'cloud', òbras 'cheek', òraj/òras 'walnut', pàūk 'spider', pèlin 'wormwood', pläč 'cry, sob', pòtok 'brook', pötrēs 'earthquake', pr̈st 'finger', räk 'crab', rät 'war', röb 'slave', röđāk 'cousin', sän 'dream' (G sg snä), sïr 'cheese', skök 'jump', slög 'syllable', súsid 'neighbor', svëkar 'father-in-law' (G sg svëkra), tèret 'burden', tröšak 'expense' (G sg tröška), ùčitel, 'teacher', üglèn 'coal', üjac 'uncle' (G sg ûjca), ùnuk 'grandson', vëpar 'boar' (G sg vêpra), vinogrād 'vineyard', vìtar 'wind' (G sg vìtra), vr̈tā (G sg vìtla) 'garden', zmäj 'dragon', zët 'son-in-law', žèludac (G sg žèludca) 'stomach', etc.

\subsection{Accent paradigm $B$}

It has already been noted that nouns belonging to a.p. B have stress linked to the ending of the root in all case forms, which results in rising accents in case forms that have more than one syllable, whereas monosyllabic forms have falling accents (N\{A\} sg monosyllabic14 : other cases polysyllabic), as in sg: N bïk, GA bika 'bull'; NA bök, G bòka 'hip'; NA kḷ̂uč, G klı́čca 'key'; NA žûl, G žúḷa 'blister'.

Rising accents appear as the result of Neo-Štokavian regressive retraction of stress from any non-initial syllable that had a falling tone before the retraction: mòmak (<*momäk) 'young man', pétak ( $<$ *pētäk) 'Friday'. The result is a long rising accent if the syllable had pre-tonic length before the retraction, or if it was lengthened according to accentual rules. 15 As with the stress transmission to proclitics described in relation to a.p. A, post-tonic length is found in the syllable following the newly stressed one if the stress is moved from a long (falling) accent: gospòdār 'master', pàstīr 'shepherd', vòjnīk 'soldier'.

A falling tone in polysyllabic case forms can be found in the $\mathrm{V}$ sg of a number of nouns denominating (male) persons: V sg dēbīlu 'idiot', čüdāče 'eccentric', jünāče 'hero', lüđāče 'lunatic', vöjnīče 'soldier'. A falling tone is also found in $\mathrm{G}$ pl pêtāka 'Fridays', pîvācā 'roosters', whereas other examples have a falling : rising variation in $\mathrm{G}$ pl mömākāamomákā 'young men', pöslōvā/pòslōvā ‘jobs'.

12 The noun does not have a plural form, but a collective one, which declines like $\bar{e}$-type nouns, but remains a.p. A: N bräća, G bräćé, D bräcí, etc.

13 The L sg form differs from the D sg. Declension: NA sg öbičāj, G sg öbičāja, D sg öbičāju, L sg običáju, I sg öbičājon/öbičājen, $\mathrm{N}(\mathrm{V})$ pl öbičăji, G pl öbičājāa, DLI pl öbičājīn/ öbičājima(n), A pl öbičāje.

14 Stress movement to the proclitic is possible in these case forms.

15 Cf. Ćurković (2014: 106-112), Kapović (2003, 2005, 2006a, 2008, 2010, 2015). 
Tables 5-8 show examples of short and long monosyllabic a.p. B nouns, as well as polysyllabic nouns with and without post-tonic length.

Table 5: Declension of köń 'horse'

\begin{tabular}{|c|c|c|}
\hline & sg & pl \\
\hline $\mathbf{N}$ & köń & kòni \\
\hline$\overline{\mathbf{G}}$ & kòna / od kòna & kóńa / od kóńā \\
\hline D & kònu & kònīn/kònima(n) \\
\hline $\mathbf{A}$ & kòna / na kòna & kòne / za kòne \\
\hline $\mathbf{V}$ & köńu & kòni \\
\hline $\mathbf{L}$ & o kònu & o kònīn/kònima(n) \\
\hline I & kònon/kònen & kòninn/kònima(n) \\
\hline
\end{tabular}

Table 6: Declension of kḷ̂́č 'key'

\begin{tabular}{|c|c|c|}
\hline & sg & pl \\
\hline$\overline{\mathbf{N}}$ & klı̂̌č & klúči \\
\hline $\mathbf{G}$ & klúča / od klúča & klúčca / od klı́čca \\
\hline D & kḷúču & klúčìn/klúčima(n) \\
\hline $\mathbf{A}$ & kḷ̂uč /nà kḷūč & kḷuče / na kḷúče \\
\hline $\mathbf{V}$ & kḷ̂uču & klúči \\
\hline $\mathbf{L}$ & o klúču & o klúúčn/klúčima(n) \\
\hline I & klúčon/klúčen & klúčĩn/klúčima(n) \\
\hline
\end{tabular}

Table 7: Declension of lóvac 'hunter'

\begin{tabular}{|c|c|c|}
\hline & sg & pl \\
\hline$\overline{\mathbf{N}}$ & lóvac & lóvci \\
\hline $\mathbf{G}$ & lóvca / od lóvca & lôvācā / òd lōvācā \\
\hline D & lóvcu & lóvcīn/lóvcima(n) \\
\hline $\mathbf{A}$ & lóvca / na lóvca & lóvce / za lóvce \\
\hline $\mathbf{V}$ & lôvče & lóvci \\
\hline $\mathbf{L}$ & olóvcu & o lóvcīn/lóvcima(n) \\
\hline I & lóvcon & lóvcīn/lóvcima(n) \\
\hline
\end{tabular}

Table 8: Declension of pàstīr 'shepherd'

\begin{tabular}{|c|c|c|}
\hline & sg & pl \\
\hline$\overline{\mathbf{N}}$ & pàstīr & pastíri \\
\hline $\mathbf{G}$ & pastira / od pastíra & pastírā /od pastírā \\
\hline D & pastíru & pastírin/pastírima(n) \\
\hline $\mathbf{A}$ & pastíra / na pastíra & pastire / na pastire \\
\hline $\mathbf{V}$ & pästīru & pastíri \\
\hline $\mathbf{L}$ & o pastíru & o pastírin/pastírima(n) \\
\hline I & pastíron & pastírīn/pastírima(n) \\
\hline
\end{tabular}


Nouns that belong to a.p. B: bïk 'bull', bîž 'pea', bôr 'pine', brîst 'elm', döm 'home', đâk 'pupil', đôn 'sole', gospòdār 'master', grîj 'sin', gröb 'grave', grim (and grm) 'bush', jèčam (G sg jèčma) 'barley', jěž 'hedgehog', klòbūk 'hat', klı̂ǔ 'key', kòlāč 'cookie', kön' 'horse', kòtāč 'wheel', kòvāč 'smith', krâl 'king', krîž 'cross', kût 'corner', lùg 'ash', mìjūr 'bladder', mîr 'peace', mòmak (G sg mòmka) 'young man', nôž 'knife', òkvīr 'frame', òrā (G sg órla) 'eagle', òtac (òca) 'father', òvan (G sg óvna) 'ram', pàs 'dog' (G sg pàsa), pàstīr 'shepherd', pétak (G sg pétka) 'Friday', pívac (G sg pívca) 'rooster', pòsā (G sg pòsla) 'job', pôd 'floor', pöp 'priest', pût 'way', râst 'oak', rážań (G sg rážńa) 'broach', rùkāy 'sleeve', sèlāak 'villager', slön 'elephant', snöp 'bundle', spûž ‘snail', stô (G sg stòla) 'table', stòmāk 'stomach', strîc 'uncle', stûp 'column', sûd 'court', vô (G sg vòla) 'ox', tôp 'cannon, top', tvör 'skunk', vòjnīk 'soldier', zglöb 'joint', zìdār 'mason', žìvot 'life', etc.

\subsection{Accent paradigm C}

Nouns declining following the pattern of the mobile paradigm have the stress drawn to the beginning or the end of the phonetic word. The accent is initial in all cases except the L sg and GDLI pl, which have dominant suffixes and attract the stress towards the end of the word. In the local dialect of Bitelić, this results in the realization of rising accents in those case forms, unless they are generalized

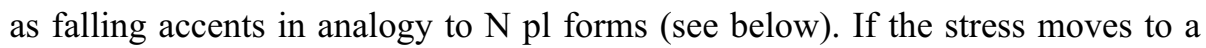
proclitic, the result is accent skipping; i.e., falling accents on the initial syllable of the proclitic: N sg môst, G sg mösta : prïko mosta 'bridge'.16

Another prominent feature of a.p. $\mathrm{C}$ is lengthening of monosyllabic forms (brôj 'number', brôd 'ship'). The originally short vowel is seen after the addition of inflectional suffixes: G sg bröja, bröda. Originally long syllables remain long after the addition of inflectional suffixes: $\mathrm{N}$ sg dân, G sg dâna 'day'; but many examples are nonetheless shortened in the plural polysyllabic forms: $\mathrm{N} \mathrm{sg} s n \hat{\imath} g, \mathrm{G} \mathrm{sg}$ snîga, $\mathrm{N}$ pl snïgovi 'snow', N sg rêp, G sg rêpa, $\mathrm{N}$ pl rëpovi 'tail'.

Tables 9-12 show examples of a.p. C for long and short monosyllabic and polysyllabic words.

16 It should be recalled that the stress transmission seen in a.p. A results in rising tones on the last syllable of the proclitic. This is the main difference between these two a.p. types because the result of accent skipping in a.p. $\mathrm{C}$ is a falling accent on the first syllable of the proclitic. 
Table 9: Declension of grâd 'city'

\begin{tabular}{|c|c|c|}
\hline & sg & pl \\
\hline $\mathbf{N}$ & grâd & grädovi \\
\hline $\mathbf{G}$ & grâda / ìz grāda & gradóvā / grädōvā / iz gradōvā \\
\hline D & grâdu & gradòvīn/grädovima(n) \\
\hline $\mathbf{A}$ & grâd / ü grād & grädove \\
\hline $\mathbf{V}$ & grâde & grädovi \\
\hline$\underline{\mathbf{L}}$ & u grádu & u gradòvīn/grädovima(n) \\
\hline I & grâdon & gradòvīn/grädovima(n) \\
\hline
\end{tabular}

Table 10: Declension of môst 'bridge'

\begin{tabular}{|c|c|c|}
\hline & sg & pl \\
\hline $\mathbf{N}$ & môst & möstovi \\
\hline G & mösta / prïko mosta & mostóvā / öd mostōvā \\
\hline D & möstu & mostòvīn/möstovima(n) \\
\hline $\mathbf{A}$ & môst / nä mōst & möste / nä mostove \\
\hline $\mathbf{V}$ & möstu & möstovi \\
\hline $\mathbf{L}$ & ö mostu / na mòstu & na mostòvīn/möstovima(n) \\
\hline I & möston & mostòvīn/möstovima(n) \\
\hline
\end{tabular}

Table 11: Declension of $\boldsymbol{k o ̈ m a ̄ d ~ ' p i e c e ' ~}$

\begin{tabular}{|c|c|c|}
\hline & sg & pl \\
\hline $\mathbf{N}$ & kömād & kömādi \\
\hline $\mathbf{G}$ & kömāda / öt komāda & komádā / iz komádā \\
\hline D & kömādu & komádimaīn/komádima(n) \\
\hline $\mathbf{A}$ & kömād / nä komād & kömāde / nä komāde \\
\hline $\mathbf{V}$ & kömādu & kömādi \\
\hline $\mathbf{L}$ & u komádu & u komádīn/komádima(n) \\
\hline I & kömādon & komádīn/komádima(n) \\
\hline
\end{tabular}

Table 12: Declension of nökat 'nail'

\begin{tabular}{|c|c|c|}
\hline & sg & pl \\
\hline $\mathbf{N}$ & nökat & nökti \\
\hline $\mathbf{G}$ & nökta / ïspo nokta & nòktijū / sa nòktijū \\
\hline D & nöktu & nòktīn/nòktima(n) \\
\hline $\mathbf{A}$ & nökat / ü nokat & nökte / nä nokte \\
\hline $\mathbf{V}$ & nöktu & nökti \\
\hline$\underline{\mathbf{L}}$ & na nòktu & o nòktīn/nòktima(n) \\
\hline I & nökton & nòktīn/nòktima(n) \\
\hline
\end{tabular}


Nouns that belong to a.p. C: bîs 'anger', bîg 'escape', brîg 'hill', brîd 'edge', brôd (G sg bröda) 'ship', brôj (G sg bröja) 'number', cvît 'flower', crîp 'roof tile', cr̂̀ y/ cr̂̀ (G sg cr̈va) 'worm', čâr 'charm', dâh 'breath', dân 'day', drôb (G sg dröba) 'stomach', drûg 'friend', glâs 'voice', glîb 'mud', gńôj (G sg gńôja) 'manure’, grâd 'city', klâs 'ear (of corn, rye)', kömād 'piece', krûg 'circle', kvâs 'yeast', lâd 'shade', lêd (G sg lëda) 'ice', lìk 'cure, form, character', lîs 'coffin', lîst 'leaf', lôv 'hunt', lôj (G sg löja) 'tallow', lûk 'bow', mêd (G sg mëda) 'honey', mìsēc 'month, moon', mlâz 'gush', môst (G sg mösta) 'bridge', mrâk 'darkness', mrây 'ant', mûž 'husband', nîz 'row', nökat (G sg nökta) 'nail', öbzīr 'consideration', pâd 'downfall', pân' 'stump', pîr 'wedding', plämēn 'flame', plês 'dance', plôd (G sg plöda) 'fruit, offspring', pöglēd 'view', prämēn 'lock (of hair)', pr̈stēn 'ring', pûk 'people', râst 'growth', rêd 'order, row', rêp 'tail', rôd (G sg röda) 'gender, kin', rôj (G sg rôja) 'swarm', rûb 'edge', sîn 'son', slôj (G sg slöja) 'layer', slüčāj 'case', smîj 'laughter', smrâd 'stench', snîg 'snow', sökō (G sg sökola) 'hawk', stân 'flat', stâs 'stature', stî̀ 'shame', svît 'world, people', šûm 'murmur', tôk 'flow', trâg 'trail, trace', tr̈k 'sprint', trûd 'effort', $\hat{u} m$ 'mind', vîk 'wolf', zêc 'rabbit', zîd 'wall', znôj (G sg znöja) 'sweat', žâr 'fervor', etc.

\subsection{Subtypes $\mathrm{B}-\mathrm{A}(\mathrm{B}-\mathrm{A} / \mathrm{B})$ and $\mathrm{C}-\mathrm{A}$}

As mentioned before, certain nouns decline following one accent paradigm in the singular and another in the plural forms. In the $a$-type masculine noun declension, two such groups have been isolated. Both of the subtypes tend to generalize the plural forms similarly to a.p. A, whereas they are different in the singular forms because the declensions belong to a.p. B and $\mathrm{C}$. The nouns that belong to subtype $\mathrm{B}-\mathrm{A} / \mathrm{B}$ follow a.p. $\mathrm{B}$ if there is no plural infix, and, if the infix is present, the plural forms decline according to a.p. A.

Tables 13-16 show examples for the accent paradigm subtypes in Bitelić.

\section{Table 13: Declension of čàs 'moment' (B-A)}

\begin{tabular}{|c|c|c|}
\hline & sg & pl \\
\hline $\mathbf{N}$ & čàs & čàsovi \\
\hline $\mathbf{G}$ & čàsa / od čàsa & čàsōvāa /ò časōva \\
\hline D & č̀̀su & čäsovin/čäsovima(n) \\
\hline $\mathbf{A}$ & čàs / zà čas & čäsove / nà časove \\
\hline $\mathbf{V}$ & čăsu & čàsovi \\
\hline $\mathbf{L}$ & o čàsu & ò časovīn / čäsovima(n) \\
\hline I & čàson & čäsovin/čäsovima(n) \\
\hline
\end{tabular}


Table 14: Declension of $\boldsymbol{k v a ̂ r}$ 'malfunction' (B-A)

\begin{tabular}{|c|c|c|}
\hline & sg & pl \\
\hline $\mathbf{N}$ & $k v a ̂ r$ & kvärovi \\
\hline$\overline{\mathbf{G}}$ & kvára / od kvára & kvärōva / òd kvarōvā \\
\hline D & kváru & kvärovīn/kvärovima(n) \\
\hline $\mathbf{A}$ & kvâr / nä kvār & kvärove / nà kvarove \\
\hline $\bar{V}$ & kvâru & kvärovi \\
\hline $\mathbf{L}$ & u kváru & kvärovīn/kvärovima(n) \\
\hline I & kváron & kvärovīn/kvärovima(n) \\
\hline
\end{tabular}

Table 15: Declension of $\boldsymbol{d z ̌ e ̀ p ~ ' p o c k e t ' ~}(\mathrm{B}-\mathrm{A} / \mathrm{B})$

\begin{tabular}{|c|c|c|c|}
\hline & sg & pl & pl \\
\hline$\overline{\mathbf{N}}$ & $d z \check{z} p$ & džèpi & džëpovi \\
\hline $\mathbf{G}$ & ď̃èpa / iž džèpa & 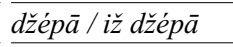 & džëpōvā / iž džepōvā \\
\hline D & $d z ̌ e ̈ p u$ & džèpinn/džèpima(n) & džëpovīn/džëpovima(n) \\
\hline $\bar{A}$ & džëp / $\dot{u} d \check{z} e p$ & džèpe / u džèpe & džèpove / ù džepove \\
\hline V & džëpe & $d z \check{e ̀ p i}$ & $d z \check{e ̈ p o v i}$ \\
\hline $\mathbf{L}$ & $o$ džèpu & džèpīn/džèpima(n) & džëpovīn/džëpovima(n) \\
\hline I & džèpon & džèpīn/džèpima(n) & džëpovīn/džëpovima(n) \\
\hline
\end{tabular}

Table 16: Declension of skûp 'assembly' (C-A)

\begin{tabular}{|c|c|c|}
\hline & sg & pl \\
\hline $\mathbf{N}$ & skûp & sküpovi \\
\hline $\mathbf{G}$ & skúpa / sa skúpa & sküpōvā / sä skupōvā \\
\hline D & skûpu & sküpovīn/sküpovima(n) \\
\hline $\mathbf{A}$ & skûp / nä skūp & sküpove / nä skupove \\
\hline $\mathbf{V}$ & skûpe & sküpovi \\
\hline $\mathbf{L}$ & o skúpu & o skùpovīn / sküpovima(n) \\
\hline I & skûpon & sküpovīn/sküpovima(n) \\
\hline
\end{tabular}

Nouns that belong to a.p. B-A: čâs 'moment', kmët 'peasant', kvâr 'malfunction', lëš 'corpse', mïš 'mouse', mlïn 'mill', rôg 'horn'.

Nouns that belong to a.p. B-A/B: bät 'maul', br̈k 'moustache', čêp 'cork', $d v o ̂ r$ 'court, courtyard', džêp 'pocket', gr̈̌̌ 'cramp', žûl 'blister'.

Nouns that belong to a.p. C-A: bôg 'god', bök 'hip', cär 'emperor', čvôr 'knot', dâr 'present', dîg 'debt', nôs 'nose' plîg 'plough', râj 'heaven', skîp 'assembly'.

\section{Concludsion}

This article considers the NŠI local dialect of Bitelić, a village in the vicinity of Sinj. It has been determined that it belongs to NŠI, and it was further defined as one of the local dialects belonging to the continental Dalmatian subdialect, according to the division introduced in this article on the basis of recent fieldwork by the 
author and existing dialectology studies. The most important information about the accentual system of Bitelic is provided at the end of the article's introduction.

The synchronic inflection of $a$-type nouns is then introduced, along with its most prominent NŠI features. Special attention is given to differentiating the A sg case form for nouns with animate and inanimate denotations. The inflectional suffixes for the I sg and the plural infix -ov- are also considered, as well as their distribution through NŠI.

The accent paradigms are introduced by their most prominent features (stress mobility, stress position relative to the root, transmission or skipping of stress to the proclitic, and plural mergers). Each accent paradigm is further described, and examples for different inflections of the paradigms are given, followed by a list of examples that belong to the paradigm in question. The final section of the article's central part takes subtypes of the paradigms into closer consideration and exemplifies them.

The analysis of $a$-type nouns in Bitelić shows that there are a number of morphological archaisms (e.g., the difference between the D and L sg in a.p. A and C, but with exceptions), as well as innovations (such as generalizations and analogies, or the emergence of subtypes a.p. B-A, a.p. B-A/B, and a.p. C-A) in the paradigmatic structures observed, which indicates a tendency towards generalization of the plural paradigms towards a.p. A. Nonetheless, it can be concluded that, although the local dialect of Bitelić differs from other NŠI local dialects in certain features, it is still an integral part of a larger NŠI continuum, extending from its homeland in the heart of the Balkan Peninsula to the other side of the world, the Australian diaspora.

\section{BIBLIOGRAPHY}

Bošnjak Botica - Menac-Mihalić 2006 = Tomislava Bošnjak Botica - Mira Menac-Mihalić, Vokalizam i akcentuacija govora Lovrećana, Rasprave Instituta za hrvatski jezik i jezikoslovlje (Zagreb) 32 (2006), 25-43.

Čilaš Šimpraga $\mathbf{2 0 1 0}$ = Ankica Čilaš Šimpraga, Ikavski štokavski govori između rijeke Krke i Neretve, in: Prinosi hrvatskoj dijalektnoj fonologiji, ed. Mijo Lončarić, Split: Književni krug Zagreb: Institut za hrvatski jezik i jezikoslovlje, 2010, 160-224.

Ćurković 2014 = Dijana Ćurković, Govor Bitelića: doktorska disertacija, Filozofski fakultet u Rijeci, Rijeka: [D. Ćurković], 2014. - Duplicated manuscript. 〈https://bib.irb.hr/datoteka/705585. Doktorat_Curkovic.pdf $\rangle$

Kapović 2003 = Mate Kapović, Razvoj starih dugih samoglasa u hrvatskom i ostalim slavenskim jezicima, Filologija (Zagreb) 41 (2003), 51-82.

Kapović 2005 = Mate Kapović, Nove duljine u hrvatskom jeziku (nakon općeslavenskoga razdoblja), Filologija (Zagreb) 44 (2005), 51-62.

Kapović 2006 = Mate Kapović, Toponimija sela Prapatnice u Vrgorskoj krajini, Folia onomastica Croatica (Zagreb) 15 (2006), 113-131.

Kapović 2006a = Mate Kapović, Naglasne paradigme o-osnova muškoga roda u hrvatskom, Rasprave Instituta za hrvatski jezik i jezikoslovlje (Zagreb) 32 (2006), 159-173.

Kapović 2008 = Mate Kapović, Razvoj hrvatske akcentuacije, Filologija (Zagreb) 51 (2008), 1-39.

Kapović 2010 = Mate Kapović, Naglasak o-osnova muškoga roda u hrvatskom - povijesni razvoj, Filologija (Zagreb) 54 (2010), 51-109. 
Kapović 2015 = Mate Kapović, Povijest hrvatske akcentuacije 1: fonetika, Zagreb: Matica hrvatska, 2015.

Kurtović Budja 2009 = Ivana Kurtović Budja, Govori Makarskoga primorja (fonologija i morfologija): doktorska disertacija, Filozofski fakultet u Zagrebu, Zagreb: [I. Kurtović Budja], 2009. - Duplicated manuscript.

Lisac 2003 = Josip Lisac, Hrvatska dijalektologija 1: hrvatski dijalekti i govori štokavskog narječja i hrvatski govori torlačkog narječja, Zagreb: Globus, 2003.

Lisac 2003a = Josip Lisac, Fonologija novoštokavskoga ikavskog dijalekta, Rasprave Instituta za hrvatski jezik i jezikoslovlje (Zagreb) 29 (2003), 173-180.

Lisac 2005 = Josip Lisac, Proučavanja hrvatskih štokavskih organskih idioma, Kolo 1 (2005). 〈http:// www.matica.hr/kolo/300/Proučavanja hrvatskih štokavskih organskih idioma/>

Lisac 2006 = Josip Lisac, Hrvatska dijalektologija od 1945. do 2005., Croatica et Slavica Iadertina (Zadar) 2 (2006), 105-114.

Listeš 1998 = Srećko Listeš, Klis: prošlost, toponimi, govor, Klis: Hrvatsko društvo Trpimir, 2005.

Menac-Mihalić $\mathbf{2 0 0 5}$ = Mira Menac-Mihalić, Frazeologija novoštokavskih ikavskih govora u Hrvatskoj s rječnikom frazema i značenjskim kazalom s popisom sinonimnih frazema, Zagreb: Institut za hrvatski jezik i jezikoslovlje - Školska knjiga, 2005.

Šimundić 1971 = Mate Šimundić, Govor Imotske krajine i Bekije, Djela ANUBiH (Sarajevo) 56 (1971).

Tomelić Ćurlin 2012 = Marijana Tomelić Ćurlin, O fonološkim obilježjima jezika Poljičkoga statuta i današnjega govora Srijana, Zbornik radova Filozofskoga fakulteta u Splitu (Split) 5 (2012), 195-209.

Tomelić Ćurlin - Anić 2012 = Marijana Tomelić Ćurlin - Marija Anić, Fonološki i morfološki opis kruševačkoga govora, Croatica et Slavica Iadertina (Zadar) 8 (2012), no. 2, 349-362.

Tomelić Ćurlin - Ćurković $\mathbf{2 0 1 3}$ = Marijana Tomelić Ćurlin - Dijana Ćurković, Jezik, virovanja i zaviti na Pelješcu, Lingua Montenegrina (Podgorica) 6 (2013), pt. 1, no. 11, 41-82.

Upitnik za Hrvatski dijalektološki atlas, Belgrade, 1963 (Petar Šimunović, 1966: Sinj).

\section{PovzeteK}

\section{Naglasne paradigme ajevskih samostalnikov moškega spola} v novoštokavskem ikavskem govoru naselja Bitelić na Hrvaškem V prispevku je predstavljena imenska sklanjatev samostalnikov moškega spola novoštokavskega ikavskega govora naselja Bitelić na Hrvaškem. Med dajalnikom in mestnikom ednine obstaja naglasno nasprotje. Za množinske sklanjatve so značilne nekatere analogije in posploševanja naglasnih značilnosti. Končnica rodilnika množine je vedno dolga, končnice za dajalnik, mestnik in orodnik množine pa so se izenačile z novoštokavskimi. Primeri so razvrščeni v sinhrone naglasne paradigme A, B, C in njihove podtipe. 